\title{
A model of burrow architecture and trophic modes in thalassinidean shrimp (Decapoda: Thalassinidea)
}

\author{
Roger B. Griffis ${ }^{1}$, Thomas H. Suchanek ${ }^{2}$ \\ ${ }^{1}$ Department of Biology, University of Southwestern Louisiana, Lafayette, Louisiana 70504-2451, USA \\ ${ }^{2}$ Institute of Ecology, Division of Environmental Studies, University of California, Davis, California 95616, USA \\ and \\ Bodega Marine Laboratory, PO Box 249, Bodega Bay, California 94923, USA
}

\begin{abstract}
Thalassinidean shrimp construct species-specific burrows which vary in morphology from simple ' $U$ ' or ' $\mathrm{Y}$ ' shaped tubes to more complex tiers of galleries or reticulate branches. Data on the burrow architecture of 44 species in 10 genera indicates that the morphological patterns of thalassinidean burrows are more diverse than previously recognized. Based on a review of these data and the existing information on thalassinidean feeding, we propose several generalizations in the form of a heuristic model relating burrow architecture and trophic mode in these fossorial decapods. Despite moderate levels of morphological variation between species, thalassinidean burrows can be categorized into 6 major groups based on their morphological characteristics. The 6 burrow types are distinguishable based on the presence or absence of (1) surface sediment mounds at excurrent openings, (2) seagrasses in chambers or the burrow lining, and (3) a simple ' $U$ ' shaped burrow design. Although relatively little is known about the functional significance of the different architectural patterns, each burrow type may be indicative of one of the 3 general trophic modes utilized by burrowing shrimp: (1) deposit feeding, (2) drift catching, and (3) filter/suspension feeding. Two different types of burrows are discernible within the mound-producing, deposit-feeding group, 3 distinct burrow morphotypes are associated with filter/suspension feeding, and the 6th burrow morphotype is produced by the drift catchers. The ecological significance of these 6 burrow types is discussed in addition to the effects of various environmental parameters on intraspecific variation in burrow morphology.
\end{abstract}

\section{INTRODUCTION}

Thalassinidean shrimp (Crustacea: Decapoda: Thalassinidea) are among the most common burrowing organisms of marine intertidal and shallow subtidal environments, and may be common in deep-sea habitats as well. These organisms rely on selfconstructed burrows for a wide variety of needs including shelter, reproduction, and feeding. Except for a larval phase which may be pelagic, most thalassinidean shrimp spend their entire life within the burrow. Despite the fact that some thalassinideans have important effects on local sediment characteristics (Suchanek 1983, Tudhope \& Scoffin 1984, Colin et al. 1986, Vaugelas \& Buscail 1990), nutrient cycling (Aller et al. 1983, Koike \& Mukai 1983, Waslenchuk et al. 1983, Abu-Hilal et al. 1988), and community composition (Peterson 1977, Murphy 1985, Posey 1986a, Branch \& Pringle 1987) as direct or indirect consequences of their burrowing, little is known about the functional links between shrimp ecology, feeding mode, and the morphology of the burrows. The fossorial existence of these organisms makes it difficult to quantify their behavior and activity without disturbing the burrow environment, and thus we understand relatively little of the biology of this diverse group of decapods.

Progress has been made in the study of thalassinidean shrimp using a number of methods, such as quantifying the amount of sediment ejected from 
burrows as a measure of burrowing activity (Suchanek 1983, Suchanek \& Colin 1986, Suchanek et al. 1986), conducting field transplant experiments to determine causes of zonation patterns (Posey 1986b), and simulating burrow environments under laboratory conditions so that behavioral interactions between individuals can be observed directly (Berrill 1975, Rodrigues 1983, Griffis 1988). One of the most illustrative techniques, however, has been the construction of burrow casts. The architecture of the burrows, revealed in the casts, provides a morphological window into the life of the shrimp. By comparing the architectural patterns of burrows constructed by different species, it may be possible to infer ecological differences between the taxa associated with their use of the burrow and their interaction with the surrounding environment. In combination with information on the phylogenetic relationships within the infraorder Thalassinidea, interspecific comparisons of burrows may provide insight into the evolution of the complex suite of behaviors and morphological characteristics associated with burrowing in this group.

Recent work by Dworschak (1983) and Suchanek (1985) initiated the development of an interspecific, functional morphology approach to the study of thalassinidean burrows. By reviewing the patterns of burrow morphology, Suchanek (1985) concluded that thalassinidean burrows fell into 3 major groups distinguished by shrimp feeding mode. The present paper is an evaluation and expansion of the burrow architecture/ trophic mode model with 2 specific goals: (1) to provide a synthesis of interspecific patterns of burrow morphology in the form of a model relating thalassinidean burrow architecture and trophic mode, and (2) to discuss patterns of intraspecific variation in burrow morphology in relation to different environmental conditions.

\section{METHODS}

Burrow morphology. The morphology of thalassinidean burrows has intrigued biologists for many years, and a variety of techniques have been used to determine the existing morphological patterns. Positive molds or casts of burrows were first constructed of cement or plaster of Paris (Stevens 1928, 1929). Recently, more durable polyester catalyst resins have been used to produce finely detailed reproductions of entire burrows (Shinn 1968, Atkinson \& Chapman 1984).

A wide variety of polyester bonding or molding resins are available and appropriate for making casts; the critical factor is that they are denser than seawater and will flow into the deepest regions of the burrow displacing any water that is present. The resin is poured into burrow openings at the sediment surface and allowed to harden ( 1 to $24 \mathrm{~h}$ depending on conditions). The positive burrow cast is then removed by careful digging in intertidal areas or with a suction dredge in subtidal areas. Alternatively, one can use the 'archaeological' method of burrow excavation which involves direct observation of the burrow features while carefully removing layer by layer of sediments with or without the presence of a resin cast (Vaugelas 1984). This method permits observation of burrow wall characteristics and blocked or filled burrow passages.

Classification of burrows. Burrows are classified into different morphological groups based on the presence or absence of prominent features such as (1) surface sediment mounds and (2) seagrass deposits, and then on the basis of more subtle morphological characteristics such as tiered galleries, reticulate branching, elongate shafts, or simple ' $\mathrm{U}$ ' or ' $\mathrm{Y}$ ' shaped tubes. The list of characters used in the classification of burrows is given in Table 1. Information on the characteristics of the burrow lining or matrix (sensu Dobbs \& Guckert 1988) is not used in the classification due to the lack of data on these features. Information on the morphology of burrows and the trophic mode of each species comes from our own research or from the published literature on thalassinidean shrimp. Although little quantitative information exists on how

Table 1. A list of the burrow characteristics used to classify thalassinidean burrows, and the general distribution of the characters $(+=$ present,$-=$ absent) among the 6 burrow types

\begin{tabular}{|c|c|c|c|c|c|c|}
\hline \multirow[t]{2}{*}{ Burrow character } & \multicolumn{6}{|c|}{ Burrow type } \\
\hline & 1 & 2 & 3 & 4 & 5 & 6 \\
\hline $\begin{array}{l}\text { Mound \& funnel } \\
\text { openings }\end{array}$ & + & + & - & - & - & - \\
\hline Seagrass in burrow & + & - & + & - & - & - \\
\hline Single opening & - & - & - & + & - & - \\
\hline Single ' $U$ ' & + & + & + & - & + & + \\
\hline Multiple 'U' & - & + & - & - & - & + \\
\hline Gallery branching & + & - & - & - & - & - \\
\hline Turning chambers & - & + & + & - & + & - \\
\hline Long vertical shaft & + & - & + & + & - & - \\
\hline $\begin{array}{l}\text { Narrow vertical } \\
\text { shaft or 'chimney' } \\
\text { from surface }\end{array}$ & - & - & - & + & - & - \\
\hline $\begin{array}{l}\text { Helical vertical } \\
\text { shaft }\end{array}$ & - & + & - & - & - & - \\
\hline $\begin{array}{l}\text { Deep reticulate } \\
\text { branching }\end{array}$ & - & - & - & + & - & - \\
\hline Deep single branching & - & - & + & - & - & - \\
\hline $\begin{array}{l}\text { Bulbous shafts with } \\
\text { narrow apertures } \\
\text { to surface }\end{array}$ & - & - & - & - & - & + \\
\hline
\end{tabular}


thalassinideans feed and what they consume, species are assigned to one of 3 general trophic groups using qualitative indicators of trophic status such as the morphology of mouthparts, gut content analyses, and observations of feeding. The 3 general trophic groups are as follows: (1) 'deposit feeders' if they feed by processing sediments and ingesting particles in the substratum, (2) 'drift catchers' if they actively collect plant or other material that drifts past the burrow opening and store it in the burrow; (3) 'filter/ suspension feeders' if they feed by filtering particles out of the burrow water.

\section{RESULTS}

\section{Part 1: Patterns of burrow morphology}

Thalassinidean shrimp construct species-specific burrows which vary in morphology from simple ' $U$ ' shaped tubes to more complex tiers of galleries or reticulate branching. Suchanek (1985) initially divided thalassinidean burrows into 2 groups based on the presence or absence of mounds of sediment at excurrent burrow openings, and subsequently partitioned the 'no mound' group into those with or without seagrass in burrow chambers or walls. This resulted in a 3-group model based on information from 23 species. With new information on an additional 21 species, this review of 44 species in 10 genera indicates that the patterns of thalassinidean burrow architecture are more complex than previously presented. Despite high levels of morphological variation between species (and some intraspecific variation; see Part 2), thalassinidean burrows can be categorized into 6 major groups based on their general morphological characteristics. The morphological characteristics of the 6 burrow types are documented in Table 1 and schematically illustrated in Fig. 1. Table 2 lists the thalassinidean species covered in this review, some characteristics of their burrows, and sources of the information. The taxonomic nomenclature used throughout this paper follows that of Manning (1987).

\section{THALASSINID SHRIMP BURROWS}

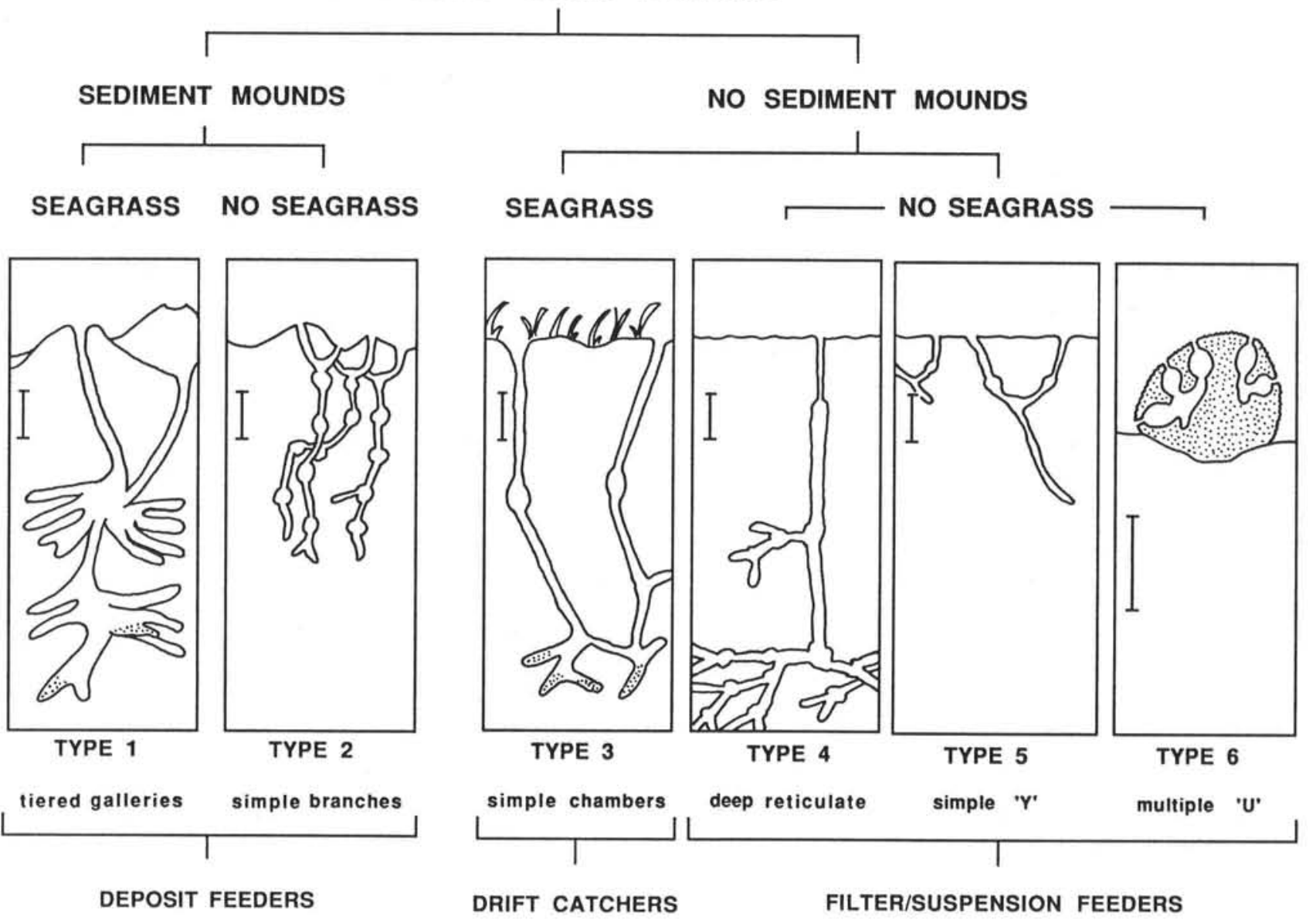

Fig. 1. Classification of thalassinidean shrimp burrows based on morphological and ecological characteristics. Illustrations of burrows are generalizations of species-specific patterns and have been horizontally compressed for presentation. See Table 1 and the text for details of specific burrow architectures. Vertical bars $=10 \mathrm{~cm}$ 
Table 2. Geographic distributions and characteristics of thalassinidean shrimp burrows. Species are listed by geographic region (tropical or temperate) and genus. Data on burrow characteristics are from measurements of adult burrows and do not represent the range of variation present in each species. Abbreviations: Habt = habitat (IT, intertidal; ST subtidal); Depth = burrow depth; Hex $=$ horizontal extension; $\mathrm{Dia}=$ burrow diameter; $\# \mathrm{Op}=$ number of burrow openings; Mnds? = surface sediment mounds present $(\mathrm{Y}$, yes; $\mathrm{N}, \mathrm{no})$; Sgrs? = seagrass present in chambers $(\mathrm{C})$, in burrow lining $(\mathrm{L})$, or not present $(\mathrm{N})$; Source $=$ citation number as listed in Literature Cited. 'Coral' and 'sponge' indicate inhabitance of these hard substrata; species lacking these labels construct burrows in soft sediments

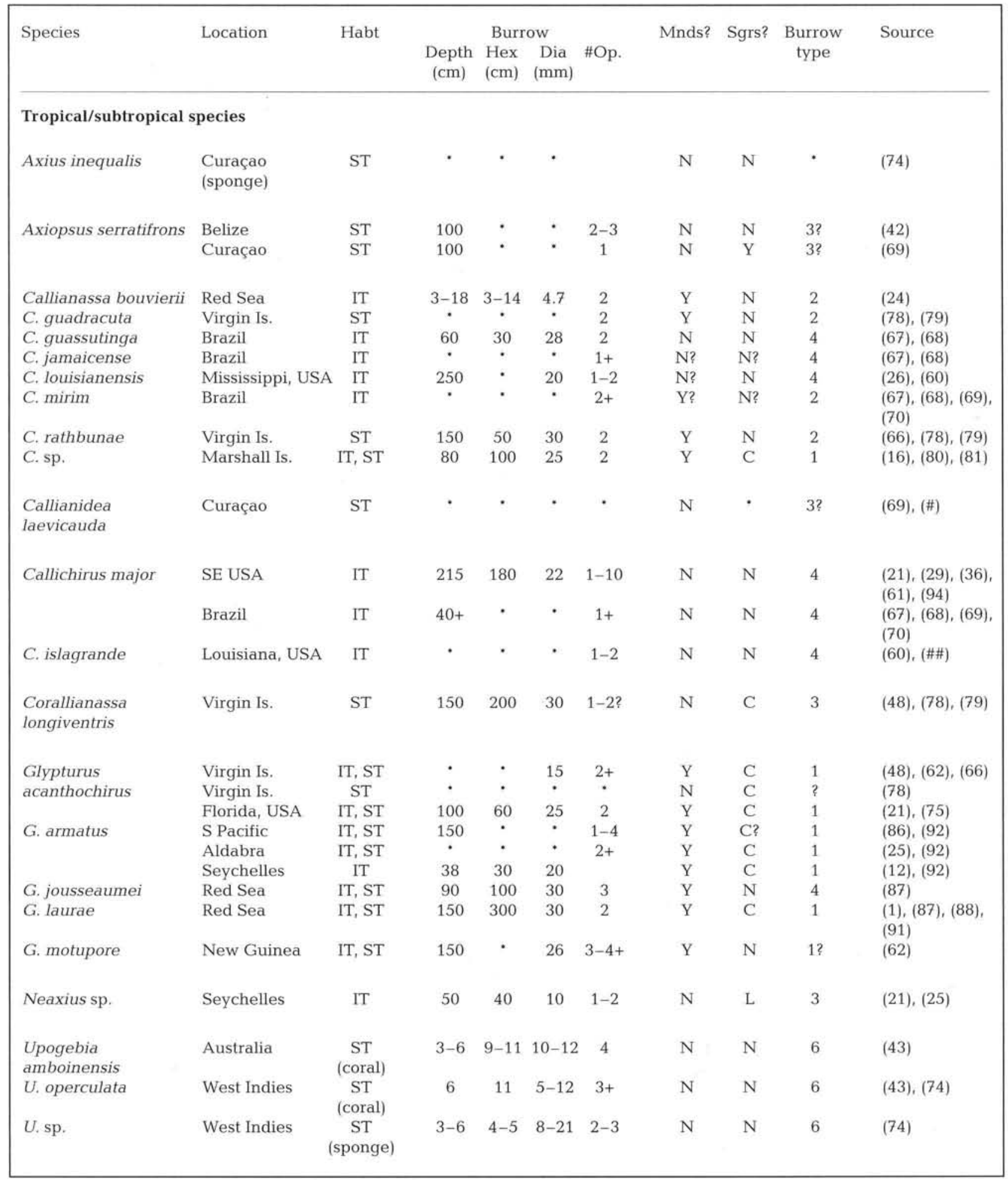


generally referred to as 'deposit feeders', distinguishing them from the 'filter/suspension feeders' and 'drift catchers' which do not regularly produce sediment mounds.

The deposit-feeding, mound-producing thalassinideans can be divided into 2 groups distinguished from each other by the presence of (1) large, tiered galleries and (2) seagrass stored in burrow chambers. Species which construct burrows with tiered galleries (Type 1; Fig. 1) produce some of the largest sediment mounds ever recorded among thalassinidean shrimp and regularly turnover large amounts of sediment (up to $3.4 \mathrm{~kg}$ (wet) $\mathrm{m}^{-2} \mathrm{~d}^{-1}$ ) (Shinn 1968, Farrow 1971, Braithwaite \& Talbot 1972, Suchanek 1983, Vaugelas 1984, Suchanek \& Colin 1986, Suchanek et al. 1986). The burrows consist of multilayered collections of elongate chambers (= galleries) resembling layered subsurface mining operations (Fig. 1, Table 1). Pieces of seagrass are packed into some of the galleries and possibly ingested directly, or scraped off other organisms after partial decomposition. However, no seagrass was found in Jaxea nocturna burrows which morphologically appear to belong in this burrow category. The Callianassa, Callichirus, Glypterus, and Jaxea species which produce these burrow types are found almost exclusively in tropical or subtropical latitudes associated with coral reef environments (Tables 3 \& 4). It is also possible that thalassinidean species inhabit various deep-sea environments. Photographs from deep-sea sites (ca $4000 \mathrm{~m}$ ) show large mounds that discharge sediment and resemble those of shallow water thalassinideans (Heezen \& Hollister 1971, Young et al. 1985). The identity of the deep-sea mound producers is not known at this time.

The second group of deposit-feeding thalassinideans produce mounds of sediment at their excurrent openings but do not exhibit the 'tiered gallery' morphology of the first group. Species in this group construct a wide variety of different burrow patterns, all of which incorporate relatively simple, twisting shafts with bulbous chambers that extend vertically from a ' $\mathrm{Y}$ '-shaped connection to the sediment surface (Type 2, Fig. 1). Burrows of these species do not show the extensive horizontal extension of the first group's gallery architecture, although they may have side branches extending horizontally from the central shaft or leading to multiple surface openings. In addition, these species rarely store large quantities of seagrass or algae in burrow chambers, although they may opportunistically make use of these materials when they enter the burrow (Griffis \& Chavez 1988). This burrow type (Type 2) is the most common form among the thalassinidean species studied thus far $(15 / 44=$

Table 3. Frequency of thalassinidean burrow types in tropical/subtropical and temperate regions. Data from sources listed in Table 1. See Fig. 1 and text for discussion of burrow types

\begin{tabular}{|lccccccc}
\hline Region & \multicolumn{5}{c|}{ Burrow type } \\
& $\begin{array}{c}1 \\
\end{array}$ & 2 & 3 & 4 & 5 & 6 \\
Total \\
$(\%)$ & $\#(\%)$ & $\#(\%)$ & $\#(\%)$ & $\#(\%)$ & $\#(\%)$ & $\#(\%)$ \\
\hline Tropical/subtropical & $5(23)$ & $5(23)$ & $4(18)$ & $5(23)$ & $0(0)$ & $3(14)$ & $22(50)$ \\
Temperate & $1(5)$ & $10(45)$ & $1(5)$ & $0(0)$ & $10(45)$ & $0(0)$ & $22(50)$ \\
Total & $6(14)$ & $15(34)$ & $5(11)$ & $5(11)$ & $10(23)$ & $3(7)$ & $44(100)$ \\
\hline
\end{tabular}

Table 4. Frequency of thalassinidean burrow types among the 7 genera for which burrow information is available. Data from sources listed in Table 1. See Fig. 1 and text for discussion of burrow types

\begin{tabular}{|c|c|c|c|c|c|c|c|}
\hline \multirow[t]{2}{*}{ Genus } & \multicolumn{7}{|c|}{ Burrow type } \\
\hline & $\begin{array}{c}1 \\
\#(\%)\end{array}$ & $\begin{array}{c}2 \\
\#(\%)\end{array}$ & $\begin{array}{c}3 \\
\#(\%)\end{array}$ & $\begin{array}{c}4 \\
\#(\%)\end{array}$ & $\begin{array}{c}5 \\
\#(\%)\end{array}$ & $\begin{array}{c}6 \\
\#(\%)\end{array}$ & $\begin{array}{l}\text { Total } \\
\#(\%)\end{array}$ \\
\hline Axiopsus & $0(0)$ & $0(0)$ & $1(100)$ & $0(0)$ & $0(0)$ & $0(0)$ & $1(2)$ \\
\hline Axius/Neaxius & $0(0)$ & $0(0)$ & $2(100)$ & $0(0)$ & $0(0)$ & $0(0)$ & $2(4)$ \\
\hline Callianassa & $1(6)$ & $13(72)$ & $0(0)$ & $3(17)$ & $1(6)$ & $0(0)$ & $18(41)$ \\
\hline Callianidea & $0(0)$ & $0(0)$ & $1(100)$ & $0(0)$ & $0(0)$ & $0(0)$ & $1(2)$ \\
\hline Callichirus & $0(0)$ & $0(0)$ & $0(0)$ & $2(100)$ & $0(0)$ & $0(0)$ & $2(4)$ \\
\hline Calocaris & $0(0)$ & $1(100)$ & $0(0)$ & $0(0)$ & $0(0)$ & $0(0)$ & $1(2)$ \\
\hline Corallianassa & $0(0)$ & $0(0)$ & $1(100)$ & $0(0)$ & $0(0)$ & $0(0)$ & $1(2)$ \\
\hline Glypturus & $4(80)$ & $1(20)$ & $0(0)$ & $0(0)$ & $0(0)$ & $0(0)$ & $5(11)$ \\
\hline Jaxea & $1(100)$ & $0(0)$ & $0(0)$ & $0(0)$ & $0(0)$ & $0(0)$ & $1(2)$ \\
\hline Upogebia & $0(0)$ & $0(0)$ & $0(0)$ & $0(0)$ & $9(75)$ & $3(25)$ & $12(27)$ \\
\hline Total & $6(14)$ & $15(34)$ & $5(11)$ & $5(11)$ & $10(23)$ & $3(7)$ & $44(100)$ \\
\hline
\end{tabular}


$34 \%$; Table 3) and is reported for species from tropical/subtropical and temperate latitudes at different frequencies ( 23 and $45 \%$, respectively; Table 3 ). Forty-one percent of the species included in this review are currently members of the genus Callianassa, and $72 \%$ of the Callianassa species produce Type 2 burrows (Table 4). However, the diversity of burrow architecture within the genus Callianassa may provide additional evidence for the speciose nature of this group which is currently under revision (R. Manning, D. Felder, pers. comms.).

The trophic mode of species which produce Type 2 burrows clearly includes some form of sediment processing (deposit feeding) where a portion of the material processed is ejected from the burrow to produce the surface mounds. Like species with Type 1 burrows, species with Type 2 burrows have high sediment processing rates (e.g. Callianassa kraussi, $12.14 \mathrm{~kg}$ (wet) $\mathrm{m}^{-2} \mathrm{~d}^{-1}$ (Branch \& Pringle 1987); Callianassa subterranea, $3.5 \mathrm{~kg}$ (dry) $\mathrm{m}^{-2} \mathrm{yr}^{-1}$ (Witbaard \& Duineveld 1989); Callianassa californiensis, $2700 \mathrm{ml}$ (wet) $\mathrm{m}^{-2} \mathrm{~d}^{-1}$ (Swinbanks \& Luternauer 1987), and the equivalent of a layer 1 to $3 \mathrm{~m}$ thick $\mathrm{m}^{-2} \mathrm{yr}^{-1}$ (Miller 1984); Glypterus laurae, $156 \mathrm{~kg}$ (wet) burrow ${ }^{-1} \mathrm{yr}^{-1}$ (Vaugelas 1984); Glypterus armatus, $3.3 \mathrm{~kg}$ (wet) $\mathrm{m}^{-2} \mathrm{yr}^{-1}$ (Vaugelas 1984). It is unclear whether this deposit feeding is simply a process of burrowing through new sediments in search of deposited material. From anecdotal observations on several species, it appears that some members of this group may rely on 'wall grazing', where organisms in the oxygenated layer of the burrow wall are consumed in the process of sorting wall sediments (MacGinitie 1934, Devine 1966, Rodrigues 1966, Ott et al. 1976, Branch \& Pringle 1987, Dworschak 1987b, Griffis \& Chavez 1988). Although little evidence exists to support this hypothesis, this method may involve 'gardening' of the burrow wall to cultivate the organisms for later consumption as suggested for other burrowing species such as Abarenicola pacifica (Hylleberg 1975). Studies showing highly elevated bacterial numbers in the lining of the burrow wall (Aller et al. 1983, Branch \& Pringle 1987, Dobbs \& Guckert 1988) indicate that the oxygenated, nutrientrich burrow environment may provide conditions for high bacterial productivity (Koike \& Mukai 1983, Aller \& Yingst 1985). In addition, the secretion of nitrogenous compounds as metabolic wastes or as mucous for use in wall construction may promote microbial growth.

High bacterial populations may in turn support elevated numbers of protozoan bacterial predators as Alongi (1985) and Alongi \& Hanson (1985) observed in tubes of the polychaete worm Capitella capitata. Hanson \& Tenore (1981) and Alongi \& Hanson (1985) suggest that with the high growth rates of the burrow wall microbial community, this type of system could support wall grazing 'deposit feeders' with little difficulty as long as the level of organics remained above some lower threshold. In one of the only detailed studies of the burrow wall, Dobbs \& Guckert (1988) found that the lining of Callianassa trilobata burrows was a productive region having more than 4 times the concentration of microbial biomass (based on lipid estimates) and equal amounts of chlorophyll $a$ as the sediment surface. Meiofauna densities were 3 to 7 times lower than in ambient sediments. The remarkable capacity of this and other thalassinideans to maintain burrows with linings which have granulometric characteristics unlike the surrounding sediment suggests that this is an important aspect of the functional morphology of the burrow, and perhaps of the feeding biology of some species as well. This is clearly one of the many areas of thalassinidean biology which requires further research. Another aspect of this granulometric selectivity is evidenced in the former Pacific Testing Grounds at Enewetak and Bikini Atolls where thalassinidean shrimp incorporate fine-grained sediments into burrow walls (Suchanek \& Colin 1986, Suchanek et al. 1986). Coincidentally in this environment, nuclear fallout particles with the highest radionuclide emissions are those in the finest sediment particle range. By mixing mucus with the finest sediment particles in this environment to cement burrow linings, thalassinideans may be responsible for a radioactive peak often found at 60 to $80 \mathrm{~cm}$ below the sediment surface, the same level at which the majority of thalassinidean burrows are located.

\section{Burrows without surface sediment mounds}

Thalassinidean shrimp burrows which lack surface sediment mounds can be divided into 4 groups based on the presence or absence of seagrass in the burrow and their morphological characteristics. Although Suchanek's (1985) distinctions between the simple ' $\mathrm{Y}$ ' shaped burrows of the 'filter/suspension feeders' (Type 5; Fig. 1) and the deep, chambered burrows of the 'drift catchers' (Type 3; Fig. 1) are maintained in this review, 2 additional burrow types $(4 \& 6)$ have been identified. Type 4 burrows are primarily reticulate branches extending horizontally from a long, vertical shaft (Fig. 1). Type 6 burrows consist of single or multiple ' $U$ ' shaped tubes with constricted apertures leading to swollen shafts (Fig. 1). Unlike burrow Types 1 to 5 which are constructed in soft sediments, Type 6 burrows are constructed within corals and sponges.

The morphological distinction between these 4 burrow types is fairly clear. The most easily recognized 
morphological feature is the simple ' $\mathrm{U}$ ' or ' $\mathrm{Y}$ ' shape burrow characteristic of Type 5 and 6 burrows. With the exception of reports that Callianassa affinis makes these types of burrows (MacGinitie \& MacGinitie 1968), the burrows are constructed exclusively by members of the genus Upogebia. Although Type 5 and 6 burrows are morphologically similar, they differ in several basic aspects. Type 5 burrows consist of at least 2 surface openings, a ' $U$ '-shaped tube connecting them, and often a relatively shallow shaft branching downward. Burrow walls are usually hard and smooth consisting of fine grain sediments, although $U$. pusilla and $U$. affinis also line their burrows with macerated seagrass (Dworschak 1983). Burrow diameter is usually slightly smaller than the occupant's carapace length, and the 2 lengths remain highly correlated through time as the individual grows (Dworschak 1987a, 1987b).

Type 6 burrows also consist of openings connected by a ' $U$ '-shaped tube. Unlike Type 5 burrows, however, Type 6 burrows usually have 2 ' $U$ '-shaped tubes connected near the bottom of the ' $U$ ', and the tube shafts are widened into small chambers which connect to the exterior through small, constricted holes (Kleemann 1984, Scott et al. 1988). Short, dead-end chambers branch from the central ' $U$ '-shaped tubes, and the burrow diameter is large enough to permit individuals to reverse direction anywhere in the burrow. These burrows are constructed exclusively within living corals (frequently of the genus Porites) and sponges (frequently of the genus Agelas) by Upogebia species which have morphological, behavioral, and possibly chemical characteristics that facilitate burrowing in these relatively hard substrata (Williams 1987, Scott et al. 1988, Williams \& Scott 1989). Type 6 burrows are lined with a mixture of organic mud, detritus, and small chips of calcium carbonate (Scott et al. 1988).

Filter feeding appears to be the primary mechanism of obtaining food in the Upogebiidae. The shallow, ' $U$ '-shaped tubes of Type 5 and 6 burrows provide efficient paths for unidirectional flow, through which Upogebia species capture suspended particles with specialized, setae-covered appendages (MacGinitie 1930, Schaefer 1970, Thompson 1972, Powell 1974, Dworschak 1987, Scott et al. 1988). Variation in feeding mode does exist among species within the group, however. Direct observations and gut content analyses of $U$. pusilla have shown that it also ingests sediment from the burrow walls after suspensionsorting the material (Dworschak 1987). The presence of plant debris and fine sediment grains in the digestive tracts of $U$. pugettensis, $U$. affinis, $U$. africana, and $U$. deltura may be indicative of more generalist suspension-feeding tendencies in these species as well (Stevens 1929, Pearse 1945, Schaefer 1970, Powell 1974, Ngoc-Ho 1984).

The 2 other types of burrows which lack surface mounds (Types 3 and 4) share several morphological characteristics. Each has a relatively long, vertical or sloping primary shaft leading to other structures deep beneath the sediment surface. In one group, a vertically sloping shaft opens into one or more chambers containing seagrass and/or other matter (Type 3; Fig. 1). In the other, the shaft may lead to a series of tunnels that spread horizontally through dichotomous branching (Type 4; Fig. 1). Representatives of both types of burrows are reported to have smooth, hard burrow walls, and Type 4 burrows frequently have distinctively narrow shafts or 'chimneys' at the burrow opening (Rodrigues 1966, 1983, Frey et al. 1978). The functional distinctions between these 2 burrow types are not clear, however. The presence of seagrass and other matter in burrow chambers and wall linings in Type 3 burrows suggests that these species may actively collect the material, possibly for consumption. This characteristic and observations of seagrass/algal capture led Suchanek (1985) to label this group of thalassinideans 'seagrass harvesters'. Corallianassa longiventris, Glypterus acanthochirus, and Axiopsis serratifrons position themselves at or near the burrow opening and have been observed capturing seagrass and other material as it passes the burrow opening (Rodrigues 1983, Suchanek 1985, Manning 1987). In contrast to most species that produce Type 2 or 5 burrows, Callianidea laevicauda produces a burrow lining on only one side of the burrow (usually the upper surface) and the burrow is large enough in diameter to permit individuals to reverse direction at any point without turning chambers. While this species has been observed capturing material at burrow openings (Rodrigues 1983), the trophic mode of this species is not clear.

Little is known about the trophic mode of species with Type 4 burrows, making the functional properties of their architectural pattern enigmatic and their placement within the model somewhat uncertain. The deep branching pattern is suggestive of a sedimentprocessing and deposit-feeding strategy, although the species rarely produce conspicuous mounds of sediment (Table 2). The smooth, hard burrow walls are suggestive of either seagrass harvesting or filter feeding, but seagrasses have not been found in the burrows and burrows generally lack the multipleopening ' $U$ '-shape efficient in filter feeding. In the field, however, Callichirus islagrande does flush sediment from the burrows on a regular basis, and in low energy areas at some tidal phases, surface sediment mounds are formed (Griffis \& Felder pers. obs.). The higher energy beach environments inhabited by this species 
normally prevent formation of these surface mounds. Nonetheless, observations of feeding in Callichirus major by Rodrigues $(1966,1983)$ and C. islagrande by Griffis \& Felder (pers. obs.) suggest that this species may combine suspension feeding with a form of 'wall grazing' deposit feeding to meet its nutritional requirements. These species produce copious amounts of fecal pellets which consist of clay-sized particles mixed with bacteria, diatoms, and other algal cells (Pohl 1946, Frankenberg et al. 1967, Phillips 1971, Griffis \& Felder pers. obs.). The relative contributions of pelagic and benthic carbon sources to the diets of these species is currently under investigation (Griffis \& Felder pers. comm.). Until we know more about the trophic mode of these species, they have been placed within the 'filter/suspension feeder' group based on the few existing observations of feeding which suggest that the species utilize some suspension feeding in a trophic mode that is functionally different than that of the true 'deposit feeders'.

\section{Part 2: Environmental effects on burrow architecture}

Although thalassinidean burrowing shrimp are relatively site specific in distribution, the range of a single species may overlap a variety of sediment types and tidal heights. Little attention has been given to the variation in burrow morphology which may exist as a function of changes in habitat. The few studies which do exist indicate that changes in habitat parameters are associated with changes in size and shape characteristics of shrimp burrows.

Several studies have observed changes in burrow characteristics with changes in tidal height. Dworschak (1987a) observed that the high intertidal burrows of Upogebia pusilla reached greater depths ( $80 \mathrm{~cm}$ max.) than burrows from subtidal areas $(20 \mathrm{~cm}$ max.). Frey et al. (1978) observed a similar pattern in Callichirus major as did Griffis (pers. obs) across an intertidal gradient in Callianassa californiensis. Changes in burrow morphology with different sediment types have also been observed for several species. Callianassa pontica creates burrows with irregular, reticulate patterns in fine sands, while in coarse sands with stones it creates simple tunnels connecting enlarged chambers (Dworschak 1987a). Although the Callianassa species studied by Farrow (1971) were not identified, they constructed shallow, horizontal branching systems in areas of thin, migratory sands. In areas of thicker deposits the burrows are vertically layered galleries. Similarly, Frey et al. (1978) observed relatively shallow, branching networks of $C$. major in areas of thin sand deposits, while in deeper sand the burrows had long vertical shafts leading to the deep, reticulate burrows. And in an experimental approach, Griffis \& Chavez (1988) showed that the burrows of $C$. californiensis and $C$. gigas were of greater volume when produced in fine grained, muddy sediments than in coarser sands.

The results of these studies indicate that changes in thalassinidean burrow architecture along tidal gradients are primarily related to burrow depth. The basic morphology of the burrow remains fairly constant within species across tidal gradients, as well as along latitudinal gradients in Callianassa californiensis and Upogebia pugettensis (Swinbanks \& Murray 1981, Swinbanks \& Luternauer 1987, Griffis \& Chavez 1988, Griffis pers. obs.). The changes in burrow architecture associated with different sediment characteristics may reflect structural limitations of the sediments to support particular types of burrow shapes. These changes may also be indicative of different behaviors associated with feeding in different sediment types. Clearly, the links between environmental variables, the biology of the shrimp, and the architecture of burrows are in need of further research.

\section{DISCUSSION}

We propose that the species-specific patterns of burrow architecture produced by thalassinidean shrimp can be generally represented by a model relating 6 burrow morphotypes to 3 primary trophic modes. Two of the 6 distinct burrow types are produced by 'deposit feeders', 3 are produced by 'filter/suspension feeders', and the last is produced by 'drift catchers'. Changes in environmental parameters such as sediment type and tidal height are associated with variation in the size of burrow components, but appear to have relatively little effect on the general shape of the burrow.

All thalassinidean burrows alter soft sediment environments by increasing the surface area of the productive, oxygenated water-sediment interface. Based on measurements of burrow volume, burrow surface area, the density of individuals and the age structure of the population, several studies have estimated that the presence of thalassinidean burrows can add an additional 1 to $9 \mathrm{~m}^{2}$ of wall surface area for every $\mathrm{m}^{2}$ of the sediment surface (Table 5 ). Measurement of water pumping rates indicate that some thalassinidean species may move large amounts of water through the burrows, perhaps equivalent to the amount of water exchanged during an average tidal flux (Dworschak 1981, Mukai \& Koike 1984). The specific effect of these increases on the surrounding community is just beginning to be quantified through rigorous study. It is clear, however, that the magnitude 
Table 5. Estimates of total burrow volume $\left(\mathrm{ml} \mathrm{m}^{-2}\right)$ and burrow wall surface area $\left(\mathrm{m}^{2} \mathrm{~m}^{-2}\right)$ for average population densities (ind. $\mathrm{m}^{-2}$ ) of several thalassinidean species. Each source is listed by number in Literature Cited

\begin{tabular}{|c|c|c|c|c|}
\hline Species & $\begin{array}{l}\text { Avg. pop. } \\
\text { density } \\
\text { (ind. } \mathrm{m}^{-2} \text { ) }\end{array}$ & $\begin{array}{l}\text { Burrow } \\
\text { volume } \\
\left(\mathrm{ml} \mathrm{m}^{-2}\right)\end{array}$ & $\begin{array}{c}\text { Burrow wall } \\
\text { surface area } \\
\left(\mathrm{m}^{2} \mathrm{~m}^{-2}\right)\end{array}$ & Source \\
\hline Callianassa bouvieri & 450 & 3220 & 2.6 & (24) \\
\hline \multirow[t]{3}{*}{ C. californiensis } & $78-170$ & $3060-6680$ & $1.2-2.7$ & (49) \\
\hline & $50-100$ & $1590-3180$ & $0.7-1.4$ & (33) \\
\hline & $100-180$ & $5650-10180$ & $1.9-3.4$ & (82) \\
\hline C. gigas & $50-100$ & $3930-7850$ & $1.6-3.1$ & (33) \\
\hline C. japonica & 20 & . & 0.25 & $(44)$ \\
\hline \multirow[t]{3}{*}{ C. subterranea } & 50 & 6000 & $1-2$ & (98) \\
\hline & 3 & 1504 & 0.42 & (9) \\
\hline & 0.95 & 321 & 0.11 & (9) \\
\hline Calocaris macandreae & 0.04 & 19 & 0.42 & (52) \\
\hline Upogebia littoralis & $200-250$ & $\cdot$ & $7-9$ & (55) \\
\hline U. pugettensis & $10-40$ & $1200-4825$ & $0.3-1.2$ & $(82)$ \\
\hline$U$. pusilla & $30-80$ & $5040-11000$ & $1-3$ & (21) \\
\hline - Data not available & & & & \\
\hline
\end{tabular}

and directionality of some effects are dependent on the type of burrow constructed. 'Filter/suspension feeders' such as Upogebia species with shallow, permanent burrows can significantly affect mineralization processes by increasing nitrification and denitrification (Aller et al, 1983, Koike \& Mukai 1983). All thalassinideans probably alter the sediment geochemistry in this way to some degree simply by occupying the burrow. Compared to 'deposit feeders', however, the 'filter/suspension feeders' appear to have relatively little effect on the organic content, turnover rate, or infaunal community of local sediments (Bird 1982, Suchanek 1985).

The burrowing activities of 'deposit feeders' have dramatic effects on the burial and excavation of organic materials, as well as the transport and mixing of sediment grain sizes (Aller 1982, Bird 1982, Roberts et al. 1982, Suchanek 1983, Tudhope \& Scoffin 1984, Vaugelas 1985, Colin et al. 1986, Suchanek \& Colin 1986, Vaugelas \& Buscail 1990). This burrowing and the resultant sediment deposition has been shown to be negatively correlated with the survival and growth of various sedentary 'filter/suspension feeders' (Ronan 1975, Peterson 1977, Murphy 1985, Posey 1986a), surface 'deposit feeders' (Brenchley 1981, 1982, Dorsey \& Synnot 1980, Bird 1982, Tamaki 1988), corals, and seagrasses (Aller \& Dodge 1974, Suchanek 1983). Depositfeeding thalassinideans have also been shown to reduce populations of meiofauna, bury microalgae (diatoms), and increase sediment bacteria numbers (Branch \& Pringle 1987). Similarly, the deep burrows of seagrass harvesters and some 'filter/suspension feeders' (Type 4) may increase sediment bacterial numbers simply by having high burrow wall surface areas. The collection and burial of plant material by the seagrass harvesters may also produce a significant nutrient 'sink', trapping material in pockets and effectively removing the carbon and nitrogen from other trophic levels for some period of time (Suchanek et al. 1986, Suchanek unpubl.). Thalassinidean shrimp, therefore, can be very important in the structuring of soft sediment environments, although the specific effect is mediated by the trophic mode and the burrow architecture of the species present.

Studies of burrow morphology have greatly enhanced our understanding of the biological complexity and ecological significance of thalassinidean shrimp. However, many questions about thalassinidean ecology and burrow architecture remain unanswered. Many of these questions fall into 3 categories concerning either (1) the functional morphology of burrows, (2) the evolution of burrowing behavior, or (3) the evolution of trophic modes within the group. This review and the work of other authors (Dworschak 1983, Suchanek 1985, Vaugelas 1990) has provided evidence of a close association between the trophic mode of a species and the architecture of the burrow. Few studies, however, have adequately evaluated the link between the morphological characteristics and the functional properties of thalassinidean burrows, especially with respect to feeding. One of the constraints on this process has been a lack of specific information on how the burrow is used in feeding and other ecologically important purposes. For example, we know almost nothing about how burrows are utilized during molting, reproduction, or interactions with other thalassinideans. Interactions between adults and juveniles, for instance, may have an effect 
on some aspects of the burrow shape, especially if juveniles use conspecific or parental burrows to establish themselves as has been suggested by Gurney (1937) in Upogebia savignyi, by Forbes (1973) in Callianassa kraussi, and by Frey \& Howard (1975) in Upogebia affinis. Although thalassinidean burrow architecture is closely associated with trophic modes, we know very little about if and how particular architectural patterns function to enhance feeding, and even less about other functional attributes of burrows associated with reproductive, behavioral, or physiological characteristics of the species. Further elucidation of the functional morphology of shrimp burrows, combined with information on the phylogenetic relationships within the group, will permit an analysis of how burrow architecture patterns have evolved in conjunction with feeding modes in thalassinidean burrowing shrimp.

Acknowledgements. We thank D.L. Felder, S. Rodrigues, and 3 anonymous reviewers for comments that improved the manuscript. Thanks to F. Chavez and M. Griffis for overall assistance. R.B.G. acknowledges financial support from the University of California at Irvine, the Louisiana Board of Regents (Grant No. LEQSF (1988-94)-GF-15), and the U.S. Minerals Management Service (Cooperative Agreement No. 14-35-0001-30470). T.H.S. acknowledges financial support from the University of California at Davis, the West Indies Laboratory (Fairleigh Dickinson University), and from NOAA/MUST (Grant No. NA80AAA02557).

\section{LITERATURE CITED}

\section{Numbers correspond to citations listed numerically in Tables 2 \& 5}

(1) Abu-Hilal, A., Badran, M., Vaugelas, J. de (1988). Distribution of trace elements in Callichirus laurae burrows and nearby sediments in the Gulf of Aqaba, Jordan (Red Sea). Mar. environ. Res. 25: 233-248

(2) Aller, R. C. (1982). The effects of macrobenthos on chemical properties of marine sediment and overlying water. In: McCall, P. L., Tevesz, M. J. S. (eds.) Animal-sediment relations. Plenum, New York, p. 53-102

(3) Aller, R. C., Dodge, R. E. (1974). Animal-sediment relations in a tropical lagoon, Discovery Bay, Jamaica. J. mar. Res. 32: 209-232

(4) Aller, R. C., Yingst, R. E. (1985). Effects of the marine deposit-feeders Heteromastus filiformis (Polychaeta), Macoma baltica (Bivalvia), and Tellina texana (Bivalvia) on averaged sedimentary solute transport, reaction rates, and microbial distributions. J. mar. Res. 43: 615-645

(5) Aller, R. C., Yingst, R. E., Ullman, W. J. (1983). Comparative biogeochemistry of water in intertidal Onuphis (Polychaeta) and Upogebia (Crustacea) burrows: temporal patterns and causes. J. mar. Res. 41: 571-604

(6) Alongi, D. M. (1985). Microbes, meiofauna, and bacterial productivity on tubes constructed by the polychaete Capitella capitata. Mar. Ecol. Prog. Ser. 23: 207-208
(7) Alongi, D. M., Hanson R. B. (1985). Effect of detritus supply on trophic relationships within experimental benthic food webs. II. Microbial responses, fate and composition of decomposing detritus. J. exp. mar. Biol. Ecol. 88: $167-182$

(8) Atkinson, R. J. A., Chapman, C. J. (1984). Resin casting: a technique for investigating burrows in sublittoral sediments. Progr. Underwat. Sci. 10: 109-115

(9) Atkinson, R. J. A., Nash, R. D. M. (1990). Some preliminary observations on the burrows of Callianassa subterranea (Montagu)(Decapoda: Thalassinidea) from the west coast of Scotland. J. nat. Hist. 24: 403-413

(10) Berrill, M. (1975). The burrowing, aggressive and early larval behavior of Neaxius vivesi (Bouvier) (Decapoda, Thalassinidea). Crustaceana 29(1): 92-98

(11) Bird, E. M. (1982), Population dynamics of thalassinidean shrimps and community effects through sediment modification. Ph. D. dissertation, Univ. of Maryland

(12) Braithwaite, C. J. R., Talbot, M. R. (1972). Crustacean burrows in the Seychelles; Indian Ocean. Palaeogeogr. Palaeoclimatol. Palaeoecol. 11: 247-264

(13) Branch, G. M., Pringle, A. (1987). The impact of the sand prawn Callianassa kraussi Stebbing on sediment turnover and on bacteria, meiofauna, and benthic microflora. J. exp. mar. Biol. Ecol. 107: 219-235

(14) Brenchley, G. A. (1981). Disturbance and community structure: an experimental study of bioturbation in marine soft bottom communities. J. mar. Res. 39: 767-790

(15) Brenchley, G. A. (1982). Mechanisms of spatial competition in marine soft-bottom communities. J. exp. mar. Biol. Ecol. 60: 17-33

(16) Colin, P. L., Suchanek, T. H., McMurtry, G. (1986). Water pumping and particulate resuspension by callianassids (Crustacea: Thalassinidea) at Enewetak and Bikini Atolls, Marshall Islands. Bull. mar. Sci. 38: 19-24

(17) Devine, C. E. (1966). Ecology of Callianassa filholi MilneEdwards 1878 (Crustacea, Thalassinidea). Trans. R. Soc. N. Z., Zool. 8: 93-110

(18) Dobbs, F. C., Guckert, G. B. (1988), Callianassa trilobata (Crustacea: Thalassinidea) influences abundance of meiofauna and biomass, composition, and physiologic state of microbial communities within its burrow. Mar. Ecol. Prog. Ser. 45: 69-79

(19) Dorsey, J. H., Synnot, R. N. (1980). Marine soft-sediment benthic community offshore from the Black Rock sewage outfall, Connewaire, Victoria, Australia. Aust. J. mar. Freshwat. Res. 31: 155-162

(20) Dworschak, P. C. (1981). The pumping rates of the burrowing shrimp Upogebia pusilla (Petagna) (Decapoda: Thalassinidea). J. exp. mar. Biol. Ecol. 52: 25-35

(21) Dworschak, P. C. (1983). The biology of Upogebia pusilla (Petagna) (Decapoda, Thalassinidea) I. The burrows. P.S.Z.N. I: Mar. Ecol. 4(1): 19-43

(22) Dworschak, P. C. (1987a). Burrows of Mediterranean Decapoda. Investigación pesq. 51 (Suppl. I): 264

(23) Dworschak, P. C. (1987b). Feeding behaviour of Upogebia pusilla and Callianassa tyrrhena (Crustacea, Decapoda, Thalassinidea). Investigación pesq. 51(1): 421-429

(24) Dworschak, P. C., Pervesler, P. (1988). Burrows of Callianassa bouvieri Nobili 1904 from Safaga (Egypt, Red Sea) with some remarks on the biology of the species. Senckenberg. maritima 20:1-17

(25) Farrow, F. E. (1971). Back-reef and lagoonal environments of Aldabra Atoll distinguished by crustacean burrows. Symp. zool. Soc. Lond. 28: 455-500

(26) Felder, D. L., Staton, J. L., Griffis, R. B. (1990). Relationships of burrow morphology to population structure in 
the estuarine ghost shrimp Lepidopthalmus louisianensis (Decapoda, Thalassinidea). Am. Zool. 30(4): 137A

(27) Forbes, A. T. (1973). An unusual abbreviated larval life in the estuarine burrowing prawn Callianassa kraussi (Crustacea, Decapoda, Thalassinidea). Mar. Biol. 22: 361-365

(28) Frankenberg, D., Coles, S. L., Johannes, R. E. (1967). The potential trophic significance of Callianassa major fecal pellets. Limnol. Oceanogr. 12: 113-120

(29) Frey, R. W., Howard, J. D. (1969). A profile of biogenic sedimentary structures in a Holocene barrier island-salt marsh complex, Georgia. Trans. Gulf-Coast Ass. geol. Socs. 19: 427-444

(30) Frey, R. W., Howard, J. D. (1975). Endobenthic adaptations of juvenile thalassinidean shrimp. Bull. Geol Soc. Den. 24: 283-297

(31) Frey, R. W., Howard, J. D., Pryor, W. A. (1978). Ophiomorpha: its morphologic, taxonomic, and environmental significance. Palaeogeogr. Palaeoclimatol. Palaeoecol. 23: $199-229$

(32) Griffis, R. B. (1988). Behavioral interactions between burrowing shrimp: effects on distribution of sympatric thalassinids. Am. Zool. 28(4): 179A

(33) Griffis, R. B., Chavez, F. L. (1988). Effects of sediment type on burrows of Callianassa californiensis Dana and C. gigas Dana. J. exp. mar. Biol. Ecol. 117: 239-253

(34) Gurney, R. (1937). Notes on some decapod Crustacea from the Red Sea. I. The genus Processa (P. aequimana, Nikoides danae, Hectarthropus). II. The larvae of Upogebia savignyi, Strahl. Proc. zool. Soc. Lond. (B) 170: 85-101

(35) Hanson, R. B., Tenore, K. R. (1981). Microbial metabolism and incorporation by the polychaete Capitella capitata of aerobically and anaerobically decomposed detritus. Mar. Ecol. Prog. Ser. 6: 299-307

(36) Hertweck, G. (1972). Georgia coastal region, Sapelo Island, U.S.A.: sedimentology and biology. V. Distribution and environmental significance of Lebensspuren and insitu skeletal remains. Senckenberg. maritima 4: 125-167

(37) Heezen, B. C., Hollister, C. D. (1971). The face of the deep. Oxford University Press, Oxford

(38) Hill, B. J. (1971). Osmoregulation by an estuarine and a marine species of Upogebia (Anomura, Crustacea). Zool. Afr. 6(2): 229-236

(39) Hill, B. J., Allanson, R. R. (1971). Temperature tolerance of the estuarine prawn Upogebia africana (Anomura, Crustacea). Mar. Biol. 11: 337-343

(40) Howard, J. D., Frey, R. W. (1975). Estuaries of the Georgia Coast, U.S.A.: Sedimentology and biology II. Regional animal-sediment characteristics of Georgia estuaries. Senckenberg. maritima 7:33-103

(41) Hylleberg, J. (1975). Selective feeding by Abarenicola pacifica with notes on Abarenicola vagabunda and a concept of gardening in lugworms. Ophelia 14: 113-137

(42) Kensley, B. (1980). Notes on Axiopsis (Axiopsis) serratifrons (A. Milne Edwards) (Crustacea, Decapoda, Thalassinidea). Proc. biol. Soc. Wash. 93(4): 1253-1263

(43) Kleemann, K. K. (1984). Lebensspuren von Upogebia operculata (Crustacea, Decapoda) in karibischen Steinkorallen (Madreporaria, Anthozoa). Beitr. Palaontol. Osterr. 11: 35-57

(44) Koike, I., Mukai, H. (1983). Oxygen and inorganic nitrogen contents and fluxes in burrows of the shrimps Callianassa japonica and Upogebia major. Mar. Ecol. Prog. Ser. 12: 185-190

(45) MacGinitie, G. E. (1930). The natural history of the mud shrimp Upogebia pugettensis (Dana). Ann. Mag. nat. Hist 6: 36-44
(46) MacGinitie, G. E. (1934). The natural history of Callianassa californiensis Dana. Am. Midl. Nat. 15: 166-177

(47) MacGinitie, G. E., MacGinitie, N. (1968). Natural history of marine animals. McGraw-Hill, New York

(48) Manning, R. B. (1987). Notes on Western Atlantic Callianassidae (Crustacea; Decapoda; Thalassinidea). Proc. biol. Soc. Wash. 100(2): 386-401

(49) Miller, M. F. (1984). Bioturbation of intertidal quartz-rich sands: a modern example and its sedimentologic and paleoecologic implications. J. Geol. 92: 201-216

(50) Mukai, H., Koike, I. (1984). Pumping rates of the mud shrimp Callianassa japonica. J. Oceanogr. Soc. Japan 40: 243-246

(51) Murphy, R. C. (1985). Factors affecting the distribution of the introduced bivalve, Mercenaria mercenaria, in a California Lagoon - the importance of bioturbation. J. mar. Res. 43: 673-692

(52) Nash, R. D. M., Chapman, C. J., Atkinson, T. J. A. Morgan, P. J. (1984). Observations on the burrows and burrowing behavior of Calocaris macandreae (Crustacea: Decapoda: Thalassinoidea). J. Zool., Lond. 202: 425-439

(53) Ngoc-Ho, N. (1984). The functional anatomy of the foregut of Porcellana platycheles and a comparison with Galathea squamifera and Upogebia deltaura (Crustacea: Decapoda). J. Zool., Lond. 203: 511-535

(54) Ohshima, K. (1967). Burrows of Japanese Thalassinidea. Chikyu Kagaku 21(1): 11-18

(55) Ott, J. A., Fuchs, B., Fuchs, R., Malasek, A. (1976). Observations on the biology of Callianassa stebbingi Borrodaille and Upogebia litoralis Risso and their effect upon the sediment. Senckenberg. maritima 8: 61-79

(56) Pearse, A. S. (1945). Ecology of Upogebia affinis (Say). Ecology 26: 303-305

(57) Pemberton, F. S., Risk, M. G., Buckley, D. E. (1976). Supershrimp: deep bioturbation in the Strait of Canso, Nova Scotia. Science 192: 790-791

(58) Pervesler, P., Dworschak, P. C. (1985). Burrows of Jaxea nocturna Nardo in the Gulf of Trieste. Senckenberg. maritima 17: 33-53

(59) Peterson, C. H. (1977). Competitive organization of the soft-bottom macrobenthic communities of southern California lagoons. Mar. Biol. 43: 343-359

(60) Phillips, P. J. (1971). Observations on the biology of mudshrimps of the genus Callianassa (Anomura: Thalassinidea) in Mississippi Sound, Gulf Res. Reps. 3: 165-196

(61) Pohl, M. E. (1946). Ecological observations on Callianassa major Say at Beaufort, North Carolina. Ecology 27: 71-80

(62) Poore, G. C. B., Suchanek, T. H. (1988). Glypturus motupore, a new callianassid shrimp (Crustacea; Decapoda) from Papua New Guinea with notes on its ecology. Rec. Aust. Mus. 40: 197-204

(63) Posey, M. H. (1986a). Changes in a benthic community associated with dense beds of a burrowing deposit feeder, Callianassa californiensis. Mar. Ecol. Prog. Ser. 31: $15-22$

(64) Posey, M. H. (1986b). Predation on a burrowing shrimp: distribution and community consequences. J. exp. mar. Biol. Ecol. 103: 143-161

(65) Powell, R. R. (1974). The functional morphology of the fore-guts of the Thalassinid crustaceans, Callianassa californiensis and Upogebia pugettensis. Univ. Calif. Publs Zool. 102: 1-41

(66) Roberts, R. R., Suchanek, T. H., Wiseman, W. J. (1982). Lagoon sediment transport: the significant effect of Callianassa bioturbation. Proc. 4th int. coral Reefs Symp., Manila 
(67) Rodrigues, S. A. (1966). Estudos sobre Callianassa: sistematica, biologia e anatomia. Ph. D. dissertation, Univ. of Sao Paulo

(68) Rodrigues, S. A. (1971). Mud shrimps of the genus Callianassa Leach from the Brazilian coast (Crustacea, Decapoda). Arq. Zool. 20(3): 191-223

(69) Rodrigues, S. A. (1983). Aspectos da biologia de Thalassinidea do Atlantico tropical americano. Publs. Inst. de Biociencias da Univ. de Sao Paulo

(70) Rodrigues, S. A., Hodl, W. (1990). Burrowing behavior of Callichirus major and C. mirim. Wiss. Film (Wien) 41: $48-58$

(71) Ronan, T. E. (1975). Structural and paleo-ecological aspects of a modern marine soft-sediment community: an experimental field study. $\mathrm{Ph}$. D. dissertation, Univ. of California, Davis

(72) Sankolli, K. N. (1972). The Thalassinoidea (Crustacea, Anomura) of Maharashtra. J. Bombay nat. Hist. Soc. 68(3): 671-682

(73) Schaefer, N. (1970). The functional morphology of the fore-gut of 3 species of decapod Crustacea: Cyclograpsus punctatus Milne Edwards, Diogenes brevirostris Stimpson, and Upogebia africana Ortmann. Zool. Afr. 5(2): 309-326

(74) Scott, P. J. B., Reiswig, H. M., Marcotte, B. M. (1988). Ecology, functional morphology, behaviour, and feeding in coral- and sponge-boring species of Upogebia (Crustacea: Decapoda: Thalassinidea). Can. J. Zool. 66: 483-495

(75) Shinn, E. A. (1968). Burrowing in recent lime sediments of Florida and the Bahamas. J. Paleont. 42: 879-894

(76) Stevens, B. A. (1928). Callianassidae from the West Coast of North America. Publ. Puget Sound Biol. Stn. 6: 315-369

(77) Stevens, B. A. (1929). Ecological observations on Callianassidae of Puget Sound. Ecology 10: 399-405

(78) Suchanek, T. H. (1983). Control of seagrass communities and sediment distribution by Callianassa (Crustacea, Thalassinidea) bioturbation. J. mar. Res. 41: 281-298

(79) Suchanek, T. H. (1985). Thalassinid shrimp burrows: Ecological significance of species-specific architecture. Proc. 5th int coral Reef Congr. Tahiti 5: 205-210

(80) Suchanek, T. H., Colin, P. L. (1986). Rates and effects of bioturbation by invertebrates and fishes at Enewetak and Bikini Atolls, Bull, mar. Sci 38(1): 25-34

(81) Suchanek, T. H., Colin, P. L., McMurtry, G. M., Suchanek, C. S. (1986). Bioturbation and redistribution of sediment radionuclides in Enewetak Atoll lagoon by callianassid shrimp: biological aspects. Bull, mar. Sci 38(1): $144-154$

(82) Swinbanks, D. D, Murray, J. M. (1981). Biosedimentological zonation of Boundary Bay tidal flats, Fraser River Delta, British Columbia. Sedimentology 28: 201-237

(83) Swinbanks, D. D., Luternauer, J. L. (1987). Burrow distribution of thalassinidean shrimp on a Fraser delta tidal flat, British Columbia. J. Paleont. 61(2): 315-332

(84) Tamaki, A. (1988). Effects of the bioturbating activity of the ghost shrimp Callianassa japonica Ortmann on migration of a mobile polychaete. J. exp. mar. Biol. Ecol. 120: $81-95$

(85) Thompson, R. K. (1972). Functional morphology of the hind-gut gland of Upogebia pugettensis (Crustacea,

This review was presented by J. Nybakken, Moss Landing, California, USA
Thalassinidea) and its role in burrow construction. Ph. D. dissertation, Univ. of California, Berkeley

(86) Tudhope, A. W., Scoffin, T. P. (1984). The effects of Callianassa bioturbation on the preservation of carbonate grains in Davies Reef Lagoon, Great Barrier Reef, Australia. J. sedim. Petrol. 54: 1091-1096

(87) Vaugelas, J. de. (1984). Preliminary observations on two types of callianassids (Crustacea, Thalassinidea) burrows in the Gulf of Aqaba (Red Sea). In: Proc. 1st Int. Symp. Coral Reef Envts. Red Sea. 1: 520-539 Jeddah

(88) Vaugelas, J. de, Saint-Laurent, M. (1984). Premieres donnees sur l'ecologie de Callichirus laurae de Saint Laurent sp. nov. (Crustace Decapode Callianassidae): son action bioturbatrice sur les formations sedimentaires du golfe d'Aqaba (Mer Rouge). C. r. Acad. Sci., Paris 298: $147-152$

(89) Vaugelas, J. de, (1985). Sediment reworking by callianassid mud-shrimp in tropical lagoons: a review with perspectives. Proc. 5th intn. coral Reef Congr., Tahiti. 6: $617-622$

(90) Vaugelas, J. de, (1990). Ecologie des callianasses (Crustacea, Decapoda, Thalassinidea) en milieu recital Indo-Pacifique. Consequences du remaniement sedimentaire sur la distribution des matières humiques, des metaux traces et des radionucleides. Doctoral d' Habilitation, Université de Nice

(91) Vaugelas, J. de, Buscail, R. (1990). Organic matter distribution in burrows of the thalassinid crustacean Callichirus laurae, Aqaba (Red Sea). Hydrobiologia 207: 269-277

(92) Vaugelas, J. de, Delesalle, B., Monier, C. (1986). Aspects of the biology of Callichirus armatus A. Milne Edwards, 1870 (Crustacea, Thalassinidea) from French Polynesia. Crustaceana 50(2): 204-216

(93) Waslenchuk, D. G., Matson, E. A., Zajac, R. N., Dobbs, F. C., Tramontano, J. M. (1983). Geochemistry of burrow waters vented by a bioturbating shrimp in Bermudian sediments. Mar. Biol. 72: 219-225

(94) Weimer, R. J., Hoyt, J. H. (1964). Burrows of Callianassa major Say, geologic indicators of littoral and shallow neritic environments. J. Paleont. 38: 761-767

(95) Williams, A. B. (1986). Mud shrimps, Upogebia, from the Eastern Pacific (Thalassinoidea: Upogebiidae), San Diego Soc. Nat. Hist. Mem. 14: 1-60

(96) Williams, A. B. (1987), Upogebia synagelas n. sp., a commensal mud shrimp from sponges in the Western Central Atlantic (Decapoda: Upogebiidae). Proc. biol. Soc. Wash. 100: 590-595

(97) Williams, A. B., Scott, P. J. B. (1989). Upogebia corallifora, a new species of coral-boring shrimp from the West Indies (Decapoda: Upogebiidae). Proc. biol. Soc. Wash. 102(2): 405-410

(98) Witbaard, R., Duineveld, G. C. A. (1989). Some aspects of the biology and ecology of the burrowing shrimp Callianassa subterranea (Montagu) (Thalassinidea) from the southern North Sea. Sarsia 74: 209-219

(99) Young, D. K., John, W. H., Richardson, M. D., Lohanick, A. W. (1985). Photographs of deep-sea Lebensspuren: a comparison of sedimentary provinces in the Venezuela Basin, Caribbean Sea. Mar. Geol. 68; 269-301

Manuscript first received: February 28, 1991

Revised version accepted: November 12, 1991 